\title{
Sustainable Platinum Recycling through Electrochemical Dissolution of Platinum Nanoparticles from Fuel Cell Electrodes
}

Sharma, Raghunandan; RodeNielsen, Kasper; BrilnerLund, Peter; BredmoseSimonsen, Søren; Grahl Madsen, Laila; MaAndersen, Shuang

Published in:

ChemElectroChem

Link to article, DOI:

$10.1002 /$ celc. 201900846

Publication date:

2019

Document Version

Peer reviewed version

Link back to DTU Orbit

Citation (APA):

Sharma, R., RodeNielsen, K., BrilnerLund, P., BredmoseSimonsen, S., GrahlMadsen, L., \& MaAndersen, S. (2019). Sustainable Platinum Recycling through Electrochemical Dissolution of Platinum Nanoparticles from Fuel Cell Electrodes. ChemElectroChem, 6(17), 4471-4482. https://doi.org/10.1002/celc.201900846

\section{General rights}

Copyright and moral rights for the publications made accessible in the public portal are retained by the authors and/or other copyright owners and it is a condition of accessing publications that users recognise and abide by the legal requirements associated with these rights.

- Users may download and print one copy of any publication from the public portal for the purpose of private study or research.

- You may not further distribute the material or use it for any profit-making activity or commercial gain

- You may freely distribute the URL identifying the publication in the public portal 


\section{FUNDAMENTALS \& APPLICATIONS \\ CHEMELECTROCHEM}

ANALYSIS \& CATALYSIS, BIO \& NANO, ENERGY \& MORE

\section{Accepted Article}

Title: Sustainable platinum recycling through electrochemical dissolution of platinum nanoparticles from fuel cell electrodes

Authors: Raghunandan Sharma, Kasper Rode Nielsen, Peter Brilner Lund, Søren Bredmose Simonsen, Laila Grahl-Madsen, and Shuang Ma Andersen

This manuscript has been accepted after peer review and appears as an Accepted Article online prior to editing, proofing, and formal publication of the final Version of Record (VoR). This work is currently citable by using the Digital Object Identifier (DOI) given below. The VoR will be published online in Early View as soon as possible and may be different to this Accepted Article as a result of editing. Readers should obtain the VoR from the journal website shown below when it is published to ensure accuracy of information. The authors are responsible for the content of this Accepted Article.

To be cited as: ChemElectroChem 10.1002/celc.201900846

Link to VoR: http://dx.doi.org/10.1002/celc.201900846 


\title{
Sustainable platinum recycling through electrochemical dissolution of platinum \\ nanoparticles from fuel cell electrodes
}

\author{
Dr. Raghunandan Sharma ${ }^{1} *$, Mr. Kasper Rode Nielsen ${ }^{1}$, Mr. Peter Brilner Lund ${ }^{1}$, Prof. Søren \\ Bredmose Simonsen ${ }^{2}$, Dr. Laila Grahl-Madsen ${ }^{3}$ and Prof. Shuang Ma Andersen ${ }^{1 *}$ \\ ${ }^{1}$ Department of Chemical Engineering, Biotechnology and Environmental Technology, University \\ of Southern Denmark, Campusvej 55, DK-5230 Odense M, Denmark \\ ${ }^{2}$ Technical University of Denmark, Department of Energy Conversion and Storage, Frederiksborgvej 399, \\ 4000 Roskilde, Denmark \\ ${ }^{3}$ IRD Fuel Cells A/S, Emil Neckelmanns Vej 15 A\&B, 5220 Odense SØ, Denmark
}

Corresponding authors: mashu@kbm.sdu.dk (S.M.A.), sharmariitk@gmail.com (R.S.)

\begin{abstract}
Recycling of the platinum group metals (PGMs) containing industrial wastes obtained from proton exchange membrane fuel cells (PEMFCs), electrolyzers, catalytic convertors and others is of high strategical importance for industrial sustainability. In this work, a highly efficient and environmentally friendly platinum recycling method through potentiodynamic cycling in dilute acidic chloride solutions is demonstrated and optimized to recover platinum from fuel cell electrodes. The process parameters such as upper and lower potential limits are optimized to be 1.6 and $0.4 \mathrm{~V}$ vs. RHE. Both the dilute acidic and the acid free $\mathrm{Cl}^{-}$containing electrolytes may be used for the dissolution. Moreover, parameters such as protocol reliability, quantification method and comparison, electrode interface structure, dissolution product and mechanisms etc. are discussed. A study in $1 \mathrm{M}$ $\mathrm{HCl}$ shows $\mathrm{Pt}$ dissolution rates as high as $\sim 30 \mu \mathrm{g} /$ cycle for potential cycling between 0.4 and $1.6 \mathrm{~V}$ (scan rate: $100 \mathrm{mV} / \mathrm{s}$ ) for a PEMFC electrode with initial Pt loading of $\sim 470 \mu \mathrm{g}$. The approach demonstrates a methodology for fast parameter screening on electrocatalyst dissolution and a proof of concept industrial recycling of spent electrocatalysts.
\end{abstract}

Keywords: Platinum nanoparticle, Dissolution, Recycling, PEMFC, Electrochemistry, Potentiodynamic 


\section{Highlights:}

- A recycling oriented Pt nanoparticle electrochemical dissolution protocol is described

- Parameters such as potential limits, electrolyte, concentration etc. are optimized

- More than $95 \%$ Pt catalyst can be dissolved using the described process

\section{Introduction}

Proton exchange membrane fuel cell (PEMFC) using hydrogen as fuel to generate electricity and water represents a fast growing clean and renewable energy conversation technology. Many countries have launched ambitious goals and concrete actions to boost the development and demonstration of the technology: Fuel Cell Projects from Department of Energy (DOE) in U.S., the Fuel Cell Programs from New Energy and Industrial Technology Development Organization (NEDO) in Japan, Fuel cells and Hydrogen Joint Undertaking (FCHJU) in Europe etc.

Among different challenges, cost reduction and material availability, especially platinum group metal (PGM) electrocatalyst, is one of the most acute factors decelerating the ultimate massive commercialization of PEMFCs. Although the required catalyst loading in a PEMFC electrode has reduced by a factor of $>20$ in the past decades, still it is too high to be competitive enough. ${ }^{[1]}$ Different strategies have been explored to optimize ${ }^{[2-3]}$, minimize,$^{[4]}$ extent $^{[5]}$ or replace $^{[6]}$ the use of the precious metals as catalysts. However, high performance PEMFCs with PGM-free catalyst still remains a challenge due to change of electrode structures and limited durability from e.g. demetalation and carbon oxidation. ${ }^{[7]}$

Platinum is the state-of-the-art and most frequently used element as electrocatalyst ${ }^{[8]}$ for PEMFCs as an emerging technology, and in many other well established industries such as automobiles (catalytic convertors), jewelry, chemical synthesis, pharmaceuticals etc., which contribute to a large demand of the element, around 260 tons with $4 \%$ steady increase annually. ${ }^{[9]}$ However, platinum is also one of 
the least abundant elements in the Earth crust, ${ }^{[10]}$ and more than $88 \%$ of the natural reserve localized in South Africa and Russia. Fehler! Textmarke nicht definiert. These may trigger market supply risk and price instability, if only primary resource is used. Therefore, PEMFC catalyst production based on secondary resource or recycling is highly attractive; moreover, secondary production has various advantageous over primary production, due to the significantly reduced energy consumption and environmental impact. ${ }^{[11]}$ Laforest et al. (2016). ${ }^{[12]}$ carried out a comprehensive environmental assessment on the life-cycle of a PEMFC membrane electrode assembly (MEA). They concluded that more than half of the environmental impact can be avoided if platinum is recovered in the end-of-life MEA.

PGM recycling is a well-established business since the 80 's. A combination of primary and secondary production using pyrometallurgical infrastructure is a common practice, especially for spent auto catalysts. ${ }^{[13]}$ However, pyrometallurgy is not feasible for high volume fuel cell MEA recycling, due to the presence of fluorine compounds. Incineration of the fluoropolymers contained in proton conductors, the hydrophobically treated gas diffusion layer using Teflon ${ }^{\circledR}$, and the catalyst layer's binding agent leads to the formation of hydrogen fluoride (HF), a toxic compound that is both harmful to health, environment and highly corrosive for the infrastructure. In addition, through incineration the valuable membrane material, perfluorinated sulfuric acid (PFSA), is essentially destroyed in the process,${ }^{[14]}$ and therefore a loss of the value. Classic hydrometallurgy has also been practiced for MEA recycling, ${ }^{[15-16]}$ where high concentration of strong acids and oxidants, e.g. $\mathrm{HNO}_{3}, \mathrm{H}_{2} \mathrm{SO}_{4}, \mathrm{HCl}$ or $\mathrm{H}_{2} \mathrm{O}_{2}$, were used for extraction. However, they are typically unpleasant to work with and have a high requirement for process infrastructure.

In recent years, platinum electrochemical dissolution phenomenon has been intensively studied by several groups, aiming either to understand the degradation mechanisms of Pt electrocatalysts through Pt dissolution under potentiostatic and/or potentiodynamic conditions, ${ }^{[17-28]}$ which lead to serious 
catalyst durability issues, or to develop a process for recovery of PGMs from the end-of-life electrocatalysts. $^{[16,29-32]}$ Significant understanding of the dissolution mechanisms under different conditions has been developed recently through the studies using a combination of electrochemical potential controlling systems and highly sensitive analytical instrumentation, such as the quartz

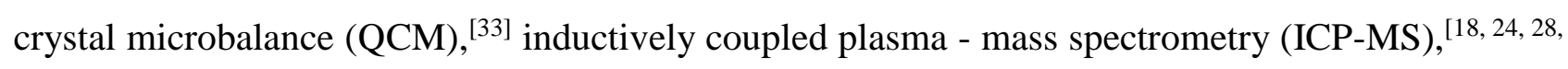
${ }^{34]}$ X-ray absorption spectroscopy ${ }^{[25]}$, etc. The direct evidence on potentiodynamic dissolution through both anodic and cathodic sweep ${ }^{[21,25,27]}$ is one of the most significant contributions in this area.

However, the emphasis of most of such pioneering works is the durability of Pt electrocatalysts under fuel cell or electrolyzer related operation conditions, ${ }^{[18,21,24-25,35-36]}$ which does not directly serve the purpose of complete Pt-dissolution or recycling. Nevertheless, comparatively faster degradation of the Pt electrocatalysts in presence of $\mathrm{Cl}^{-}$has motivated to employment of the electrochemical potential cycling to recover Pt from the spent catalysts. ${ }^{[18,28,37-38]}$ A few groups ${ }^{[39-40]}$ have further investigated Pt recycling using electrochemical treatment in $\mathrm{Cl}^{-}$containing acidic baths; nevertheless, most of the studies were carried out on bulk material, which limits the possibility for high throughput sampling, requires long treatment time and does not always represent the properties of the corresponding high surface area catalysts, which can be dissolved under comparatively mild conditions (dilute acids, room temperature).

In such a study to recover Pt from nanoparticulate Pt through potentiodynamic treatment, Latsuzbaia et al. (2015) have investigated the influence of $\mathrm{Cl}^{-}$concentration on the dissolution of $\mathrm{Pt}$ from a fuel cell electrode by potential cycling between 0.5 and $1.1 \mathrm{~V}$ in $0.1 \mathrm{M} \mathrm{HCl}$. In the selected potential window, dissolution through formation of $\mathrm{Pt}^{2+}$ species takes place to dissolve $\sim 0.35 \mathrm{mg} \mathrm{Pt}$ on a time scale of $3-5$ h. ${ }^{[41]}$ However, for large-scale applications, dissolution rates much faster than those reported are desired. Kanamura et al. (2016) have investigated Pt dissolution from MEAs by square wave potential cycling in dilute acids and suggested an optimal upper potential to be $1.4 \mathrm{~V}$ for the $\mathrm{Pt}$ 
dissolution. ${ }^{[30]}$ However, the lower potential was kept constant at $0.1 \mathrm{~V}$. Such a low value of lower potential may not be suitable for efficient Pt dissolution due to the increased probability of redeposition of the dissolved Pt species. ${ }^{[24,26,31,42]}$ Potentiodynamic dissolution through electroless manipulation of the Pt surface potential, having an advantage of its applicability irrespective of the electronic connectivity of the Pt nanoparticles, has been reported by Hodnik et al. (2016), where, high dissolution rates have been achieved by cyclic oxidation and reduction of $\mathrm{Pt}$ surface through application of oxidative and reductive gases (e.g. ozone and carbon monoxide). ${ }^{[32]}$

The current work presents feasibility and development on electrochemical platinum catalyst dissolution as a user friendly and environmentally friendly process by using potential control and dilute acidic solutions, to efficiently extract and recover platinum catalyst from its original electrode in form of soluble specious. The process demonstrates a proof-of-concept methodology for platinum group metal recycling and will bring inspiration to an economic, efficient and eco-friendly metallurgical process using electrochemistry as a platform and possibility towards commercialization. ${ }^{[31,43]}$

\section{Experimental}

\subsection{Protocol for catalyst electrochemical dissolution}

The dissolution behavior of high surface area PEMFC platinum catalyst is highly desirable and valuable information for feasibility assessment and optimization of catalyst recycling. However, platinum nanoparticles usually supported on conductive porous carbon impose several practical challenges for electrochemical dissolution studies, e.g. tedious separation steps between solid and liquid phase, , large deviation due to sample loss from reaction or processing, small sample size due to high value of the material etc. Further, for large electrode areas, connection to external power source may be important factor as poor current distribution and potential drops due to Ohmic resistance lead to inhomogeneous dissolution of $\mathrm{Pt}$. 
To avoid the aforementioned issues, a user friendly, fast screening protocol for electrochemical dissolution studies on platinum, or in general any electrocatalyst, has been developed. As presence of several metals/alloys and/or support matrices may alter the reaction mechanics leading to low accuracy in reaction kinetic quantification, a relatively simple electrode containing Pt nanoparticles (instead of other typical Pt-alloy electrodes used for PEMFCs) as the catalyst has been studied here. Main features of the procedure consist of:

- Catalyst nanoparticles stabilized in the form of electrode is used for the dissolution study

- Catalyst loading estimation by quantitative analysis, e.g. X-ray fluorescence (XRF) spectroscopy

- Electrode connection with a graphite rod and catalyst dissolution through potentiodynamic treatment (electrochemical dissolution)

- Dissolution element quantification using solution based spectroscopies, e.g. atomic absorption spectroscopy (AAS) or UV-visible spectroscopy.

- Residual element quantification using XRF

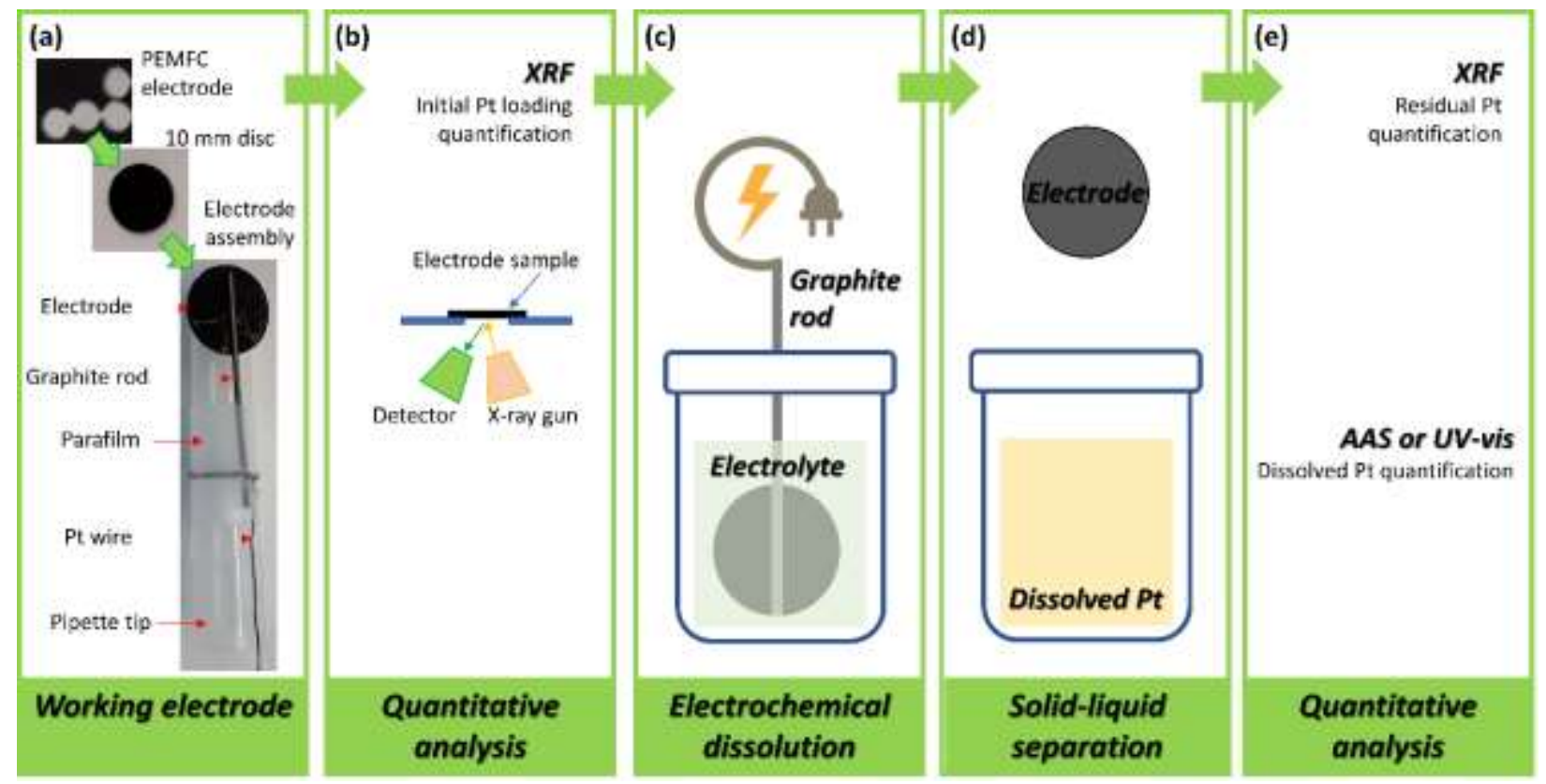

Figure 1. Schematic illustration on catalyst electrochemical dissolution evaluation protocol 


\subsection{Materials and methods}

Materials: Hydrochloric acid (1 M HCl; Reagent Ph. Eur.; BDH chemicals), Ammonium chloride $\left(\mathrm{NH}_{4} \mathrm{Cl}\right.$; purity: $>99.99 \%$; Reagent Ph. Eur.; BDH chemicals $)$, sulfuric acid $\left(\mathrm{H}_{2} \mathrm{SO}_{4}\right.$; EMSURE ${ }^{\circledR}$ grade, assay > $95-97 \%$, Merck, Germany), nitric acid $\left(\mathrm{HNO}_{3}\right.$; assay: 65\%, Sigma-Aldrich $\left.{ }^{\circledR}\right)$ and Milli-Q water (type I, resistivity $\geq 18.2 \mathrm{M} \Omega \cdot \mathrm{cm}$ at $25^{\circ} \mathrm{C}$ ) were used to prepare different electrolyte solutions. The PEMFC electrodes used in this study were prepared at IRD fuel cells A/S by spray coating of the carbon supported Pt-nanoparticles (HiSPEC $9100 \mathrm{Pt} / \mathrm{C}$ catalyst)/Ionomer ink on a gas diffusion layer (GDL; SIGRACET 35DC) to obtain a Pt loading of $\sim 0.6 \mathrm{mg} / \mathrm{cm}^{2}$ and an ionomer (Nafion ${ }^{\circledR}$ ) content of $\sim 30$ wt.\%. To investigate the effect of Ionomer content on the Pt dissolution, electrodes with Pt loadings of $\sim 0.6 \mathrm{mg} / \mathrm{cm}^{2}$ and varying Nafion® contents of $0,15,30$ and 45 wt.\% were prepared at IRD fuel cells A/S by tape casting and spraying of the HiSPEC 9100/Ionomer inks on the SIGRACET 35DC GDL.

Electrochemical studies: A three-electrode setup consisting of a working electrode (WE), a counter electrode (CE; Graphitic carbon rod; $\sim 5 \mathrm{~mm}$ diameter) and a reference electrode (RE; $\mathrm{Hg} / \mathrm{Hg}_{2} \mathrm{SO}_{4}$; REF 601 Radiometer $^{\circledR}$ ) was used for the electrochemical dissolution study. A $10 \mathrm{~mm}$ diameter sheet stamped from the catalyst coated GDL was used as the WE, while a graphite rod ( $0.5 \mathrm{~mm}$ diameter) was used as the current collector, as shown in the schematic of Fig. 1a. All potentials have been reported w.r.t. the reversible hydrogen electrode (RHE) by measuring the potential of the $\mathrm{Hg} / \mathrm{Hg}_{2} \mathrm{SO}_{4}$ electrode w.r.t. an RHE in same electrolyte and shifting the measurement potentials accordingly. A Zahner ${ }^{\circledR}$ IM6e electrochemical workstation was used to perform the electrochemical studies in different electrolytes (12 mL; no gas purging; room temperature) and under different potentiodynamic conditions, i.e., potential limits and number of potential cycles $(N)$. The electrolytes were kept 
stagnant during the dissolution study, except for the experiment to study the effect of convection flow, where stirring at $750 \mathrm{rpm}$ was applied during the potential cycling.

Dissolution quantification: Pt loadings on the WE before and after the electrochemical treatment were determined by using a calibrated Thermo Scientific Niton XL3t GOLDD+ XRF analyzer. The initial and residual Pt loading values ( $W_{0}$ and $W_{f}$, respectively) were used to determine the \%dissolution of Pt (equation 1) during the electrochemical dissolution.

$$
\% \text { dissolution }=\frac{W_{0}-W_{f}}{W 0} \times 100
$$

The amount of dissolved $\mathrm{Pt}$ in the post-dissolution electrolyte was also measured through atomic absorption spectroscopy (AAS) using a Graphite Furnace Agilent 200 Series AA analyzer. The measurements were performed using a commercial Pt standard (Sigma-Aldrich ${ }^{\circledR}$ ) of $250 \mu \mathrm{g} / \mathrm{L}$ and by diluting the electrolytes with a dilution factor (DF) of 200. Moreover, an alternative approach for determination of \%dissolution through UV-vis spectroscopy was demonstrated using a Lambda 900 UV/VIS/NIR spectrometer (Perkin Elmer). UV-Vis spectroscopy was also used to study the chemical state of the dissolved Pt species. The technique is further used to study the Pt-dissolution rates with applied potential during a potential cycle. Electrolyte samples $(100 \mu \mathrm{L})$ were collected at different potentials (potential step size: $0.2 \mathrm{~V}$ ) during an electrochemical potential cycle (start: $1.2 \mathrm{~V}$, max.: $1.6 \mathrm{~V}$, min.: $0.4 \mathrm{~V}$ and end: 1.6 ) at a scan rate of $10 \mathrm{mV} / \mathrm{s}$ in $0.1 \mathrm{M} \mathrm{HCl}$ and $0.1 \mathrm{M} \mathrm{HCl}+0.1 \mathrm{M} \mathrm{CuCl}_{2}$ electrolytes. The comparatively slow scan rate $(10 \mathrm{mV} / \mathrm{s})$ was used to enable the sample collection at a certain potential, while magnetic stirring at $1000 \mathrm{rpm}$ was used to ensure homogeneous distribution of the Pt species in the electrolyte. UV-Vis spectra of the collected electrolytes (DF: 100) were recorded to study the Pt concentration evolution with applied potential.

\section{Quantification of Pt-dissolution through UV-Vis spectroscopy:}

UV-Vis spectroscopy, a technique requiring low initial cost, may be used for quantification of the Ptdissolution in chloride containing electrolytes from the catalyst samples. The electrochemical 
dissolution of $\mathrm{Pt}$ in such baths takes place through formation of $\left[\mathrm{PtCl}_{4}\right]^{2-}$ and/or $\left[\mathrm{PtCl}_{6}\right]^{2-}$ complexes, which exhibit absorption peaks centered at $\sim 265 \mathrm{~nm}$ and $\sim 225 \mathrm{~nm}$, respectively. The concentration of $\mathrm{Pt}$ in the electrolyte can be measured by measuring the corresponding absorbance, which is directly proportional to the concentration of absorbing species in solution (Beer Lambert law). Fig. 2 shows calibration curves made for both the complexes by using commercial Pt precursors: $\mathrm{K}_{2} \mathrm{PtCl}_{4}$ solution in $0.1 \mathrm{M} \mathrm{HCl}$ for the $\left[\mathrm{PtCl}_{4}\right]^{2-}$ complex and $\mathrm{PtCl}_{4}$ solution in $0.1 \mathrm{M} \mathrm{HCl}$ for the $\left[\mathrm{PtCl}_{6}\right]^{2-}$ complex $\left(\mathrm{PtCl}_{4}+2 \mathrm{HCl} \rightarrow \mathrm{H}_{2} \mathrm{PtCl}_{6}\right)$.
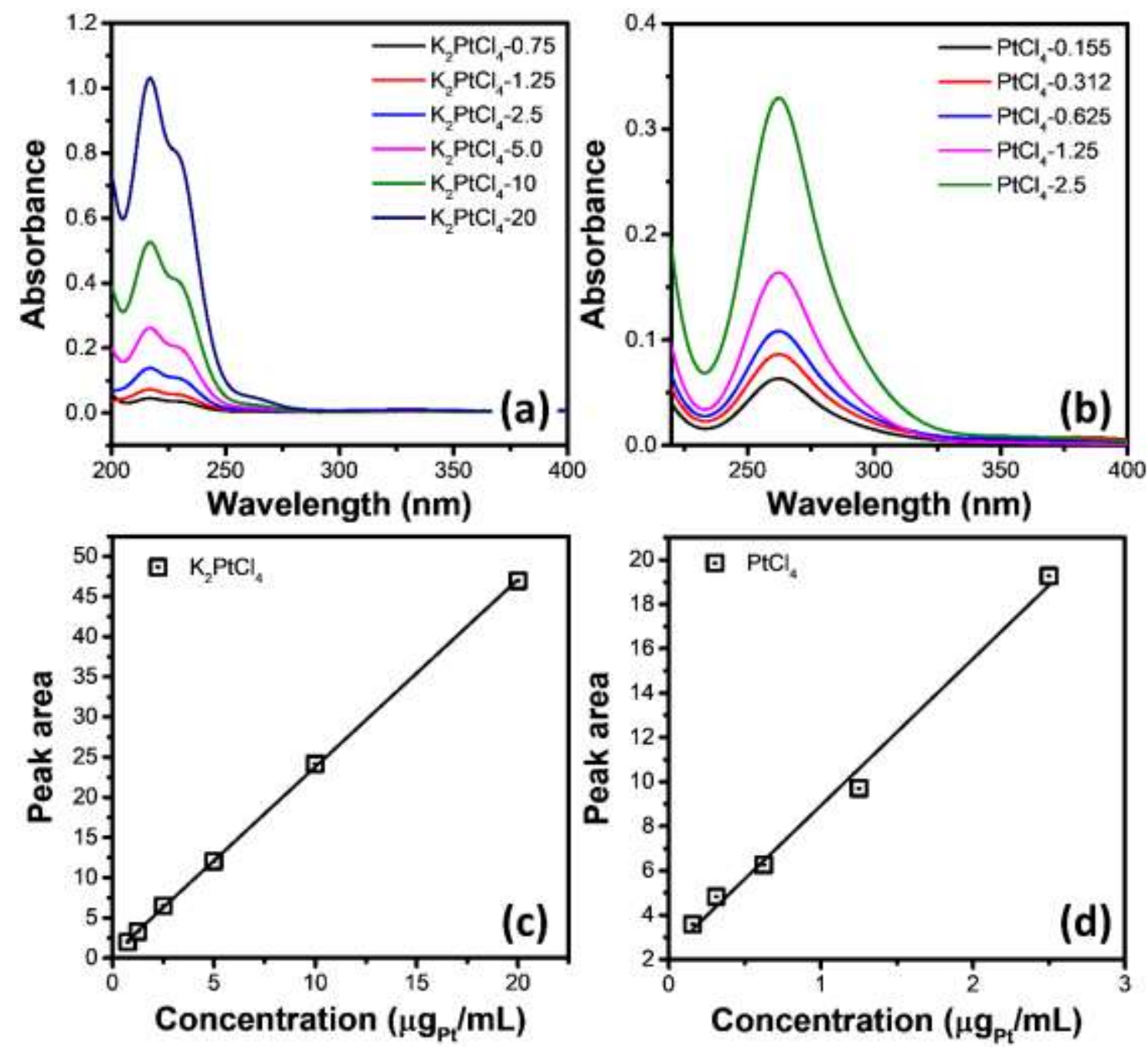

Fig. 2: UV-Vis spectra of (a) the $\mathrm{K}_{2} \mathrm{PtCl}_{4}$ solutions in $0.1 \mathrm{M} \mathrm{HCl}$ with varying $\mathrm{Pt}$ concentrations between 0.75 and $20 \mu \mathrm{g} / \mathrm{mL}$ and (b) the $\mathrm{PtCl}_{4}$ solutions in $0.1 \mathrm{M} \mathrm{HCl}$ with varying Pt concentrations between 0.155 and $2.5 \mu \mathrm{g} / \mathrm{mL}$. The Pt concentrations have been shown in legends. Variations of the 
area under the absorption peak with Pt concentrations corresponding to (c) the $\left[\mathrm{PtCl}_{4}\right]^{2-}$ and (d)

$$
\text { the }\left[\mathrm{PtCl}_{6}\right]^{2-} \text { complexes. }
$$

Structural characterizations: X-ray diffraction (XRD) patterns of the pristine and the electrochemically treated electrodes were collected using a Rigaku Miniflex 600 X-ray diffractometer (X-ray radiation: $\mathrm{Cu} \mathrm{K \alpha}(\lambda=1.5418 \AA)$ ). The Pt (111) diffraction peak at diffraction angle $(2 \theta)=$ $39.8^{\circ}$ (JCPDS\# 65-2868) was used to determine the average crystallite size of Pt-nanoparticles $(L)$ using Scherer's formula $(L=0.9 \lambda / \beta \operatorname{Cos} \theta$; where $\beta$ is the width $(2 \Delta \theta)$ of the diffraction peak, determined from the full width at half maximum (FWHM) of Lorentz distribution $(\beta=\mathrm{FWHM} \times \pi / 2)$. Finally, transmission electron microscope (TEM; JEOL 3000F) was used to observe the size distribution and the abundance of the Pt-nanoparticles in pristine and electrochemically treated electrodes. Samples for TEM imaging were prepared by dispersing the catalyst layer in ethanol ultrasonically and drop casting on a $\mathrm{Cu}$ grid.

\section{Results and discussion}

\subsection{Reliability studies}

The reliability of the dissolution protocol was carefully evaluated and is reported in Table 1 . The procedure produces relative standard deviation of less than $4 \%$ and is implemented for rest of the studies on Pt electrochemical dissolution optimization and mechanism interpretation.

Table 1. Reproducibility evaluation on dissolution studies

\begin{tabular}{cc}
\hline Experiment & Dissolution percentage \\
1 & 53.0 \\
2 & 52.2 \\
3 & 55.9 \\
Avg. & 53.7 \\
Rstdev & $3.6 \%$ \\
\hline
\end{tabular}


The dissolution protocol established in this work has several advantages. Firstly, in electrodes, catalyst powder is physically localized by polymeric binder, which provides an easy solution for solid - liquid separation; moreover, catalyst ink is supported by an electron conductive layer, which provides excellent current distribution to reach catalyst nanoparticles. These greatly simplify experimental procedures. Secondly, graphite is an easily accessible material with good conductivity and high corrosion resistance. In contrast, metallic connections may corrode and cannot guarantee stable contact, consequently degree of dissolution; moreover, metallic impurities may disturb the dissolution mechanism and lead to misinterpretation. Dissolution and residual element quantification are complementary to each other and provide cross-checking possibility; furthermore, the high sensitivity of the instruments allows for minimal material use for accurate quantitative analysis. XRF provides instant, high throughput and reliable metallic element detection. ${ }^{[44]}$ Table 2 shows a comparison of the measurements of the dissolved $\mathrm{Pt}$ amounts in $0.1 \mathrm{M} \mathrm{HCl}$ during different experiments through AAS and XRF techniques. The \%deviation of the XRF measurements from the corresponding AAS measurements lies within $\pm 5 \%$. The good correlation between the values determined through XRF and AAS suggests high reliability of the XRF technique. Further, the correspondence also suggests no significant deposition of Pt on the counter and reference electrodes during the dissolution study.

Table 2: Comparison of the measurements of the dissolved $\mathrm{Pt}$ amounts in $0.1 \mathrm{M} \mathrm{HCl}$ during different experiments through AAS and XRF techniques

\begin{tabular}{|c|c|c|c|c|c|c|c|}
\hline Electrode & $\begin{array}{c}\text { Total } \\
\text { Pt } \\
\text { loading } \\
(\mu \mathrm{g})\end{array}$ & $\begin{array}{l}\text { Vol. } \\
\text { (mL) }\end{array}$ & $\begin{array}{l}\text { AAS } \\
\text { conc. } \\
\text { (DF: } \\
200)\end{array}$ & $\begin{array}{c}\text { \%dissolut } \\
\text { ion } \\
(\mathrm{XRF})\end{array}$ & $\begin{array}{l}\text { Dissolved Pt } \\
\text { from XRF } \\
(\mu g)\end{array}$ & $\begin{array}{l}\text { Dissolved } \\
\mathrm{Pt}(\mu \mathrm{g}) \\
\text { from AAS }\end{array}$ & $\begin{array}{c}\text { \%deviatio } \\
\text { n }\end{array}$ \\
\hline
\end{tabular}




\begin{tabular}{|c|c|c|c|c|c|c|c|}
\hline $\begin{array}{c}\mathrm{S} 1 \\
\left(0.6 \mathrm{mg} / \mathrm{cm}^{2}\right)\end{array}$ & 471 & 13 & 52.2 & 27.4 & 129 & 136 & -5.1 \\
\hline $\begin{array}{c}\mathrm{S} 5 \\
\left(0.6 \mathrm{mg} / \mathrm{cm}^{2}\right)\end{array}$ & 471 & 15 & 146.5 & 89.4 & 421 & 440 & -4.3 \\
\hline $\begin{array}{c}\mathrm{S} 3 \\
(1.45 \\
\left.\mathrm{mg} / \mathrm{cm}^{2}\right)\end{array}$ & 1139 & 12 & 250.3 & 53.9 & 614 & 601 & 2.2 \\
\hline $\begin{array}{c}\mathrm{S} 4 \\
(1.45 \\
\left.\mathrm{mg} / \mathrm{cm}^{2}\right)\end{array}$ & 1139 & 12 & 417.1 & 85.6 & 975 & 1001 & -2.6 \\
\hline
\end{tabular}

\subsection{Electrochemical parameters (potential range)}

A number of electrochemical parameters, such as the potential window, waveform of the potential cycle (triangular, square, sawtooth, etc.), scan rate, etc., may be varied during the electrochemical dissolution process. Among these, the potential window, which determines the overall dissolution mechanism, is of high significance. While significant redeposition of the dissolved Pt species may take place for low potentials, higher potentials may lead to electrolysis of water, chlorine evolution and carbon corrosion, and hence, both the upper and the lower potential limits determine the overall dissolution mechanism.

To observe the electrochemical reactions during potentiodynamic treatment, cyclic voltammograms recorded by subjecting a typical Pt/C WE used in the present study to a potential cycling in $0.1 \mathrm{M}$ $\mathrm{HCl}$ at a scan rate of $10 \mathrm{mV} / \mathrm{s}$ between different potential ranges are shown in Fig. 3a. A scan rate slower than that used for the dissolution study is used to make the Faradaic peaks observable that are obscure otherwise due to large capacitive currents at a scan rate of $100 \mathrm{mV} / \mathrm{s}$ (Fig. S1; supporting information S1). For comparison, cyclic voltammogram in $1 \mathrm{M} \mathrm{H}_{2} \mathrm{SO}_{4}$ exhibiting the characteristic peaks corresponding to (i) $\mathrm{H}^{+}$adsorption, (ii) hydrogen evolution, (iii) hydrogen oxidation reaction (HOR), (iv) $\mathrm{H}^{+}$desorption, (v) Pt oxidation, (vi) oxygen evolution/carbon corrosion, (vii) Pt-Oxide 
reduction, etc., ${ }^{[45]}$ is also provided in Fig. 3a. In $0.1 \mathrm{M} \mathrm{HCl}$, the peaks corresponding to $\mathrm{H}^{+}$adsorption, $\mathrm{H}^{+}$desorption, hydrogen evolution and $\mathrm{HOR}$ become less clear probably due to $\mathrm{Cl}^{-}$coverage of the Pt surface. Peak corresponding to $\mathrm{Cl}^{-}$adsorption can be observed at $\sim 1.3 \mathrm{~V}$ during positive-going scan, while the onset of $\mathrm{Cl}^{-}$desorption during the negative-going scan takes place at $\sim 1.0 \mathrm{~V}$ and proceeds till $\sim 0.5 \mathrm{~V}$, along with the Pt-Oxide reduction. Further, large currents for potentials $>1.4 \mathrm{~V}$ during positive-going scan correspond mainly to chlorine evolution along with the oxygen evolution/carbon corrosion., while the current peak at $\sim 1.3 \mathrm{~V}$ for negative-going potentials $(>1.3 \mathrm{~V})$ is attributed to the chlorine reduction $\left(\mathrm{Cl}_{2}+2 e^{-} \rightarrow 2 \mathrm{Cl}^{-}(1.358 \mathrm{~V}){ }^{[46]}\right.$

The effect of the lower potential limit on the dissolution rate (in terms of \%dissolution from WE: 10 mm disc) of a triangular waveform was studied by keeping the upper potential limit fixed at $1.6 \mathrm{~V}$ and varying the lower potential limit between 1.0 and $0.0 \mathrm{~V}$ during potential cycling in $0.1 \mathrm{M} \mathrm{HCl}$ at a scan rate of $100 \mathrm{mV} / \mathrm{s}$ for 50 cycles. Similarly, the effect of the upper potential limit on the dissolution rate of a triangular waveform was studied by keeping the lower potential limit fixed at 0.4 $\mathrm{V}$ and varying the upper potential limit between 1.0 and $1.7 \mathrm{~V}$ during potential cycling in $0.1 \mathrm{M} \mathrm{HCl}$ at a scan rate of $100 \mathrm{mV} / \mathrm{s}$ for 50 cycles. As shown in Fig. S1 (supporting information), the shape of a voltammogram changes significantly with $N$ due to factors such as (i) the effective Pt surface area, (ii) the concentration of dissolved Pt species, (iii) the Pt-nanoparticle/carbon support interaction, (iv) the wettability of the electrode due to possible carbon corrosion from the GDL and the catalyst support and change of ionomer interface. With varying upper/lower potentials the voltammogram shapes change due to occurrence of difference redox reactions including hydrogen evolution, chlorine evolution, water electrolysis, etc.

The effect of varying the upper and lower potential limits on the \%dissolution has been shown in Fig. 3b. For the lower potential limit study (upper potential: $1.6 \mathrm{~V}$ ), no significant Pt-dissolution takes place for the lower potential higher than $0.8 \mathrm{~V}$, while the \%dissolution in specified $N$ value decreases 
for the lower potential limits below $0.4 \mathrm{~V}$. Hence, a lower potential limit of $0.4 \mathrm{~V}$ is found optimal for the Pt recovery for the studied electrodes through electrochemical dissolution. On the other hand, \%dissolution of $\mathrm{Pt}$ increases with increasing the upper potential limit from 1.0 to $1.7 \mathrm{~V}$ while keeping the lower potential limit fixed at $0.4 \mathrm{~V}$. The observed monotonous increase of the \%dissolution with increasing upper potential is in contrast to that reported by Kanamura et al. (2016), where a decrease of dissolution has been reported for potentials above $1.4 \mathrm{~V}$ during dissolution of $\mathrm{Pt}$ in $1 \mathrm{M} \mathrm{HCl}$ through square-wave potential cycling between lower potential of $0.1 \mathrm{~V}$ and varying upper potential values. ${ }^{[30]}$ This may be due to comparatively less redeposition of the dissolved Pt species at $0.4 \mathrm{~V}$ in the present study as compared to that at $0.1 \mathrm{~V}$ for the earlier report. Chlorine evolution at potentials $>1.36 \mathrm{~V}$ may also affect the Pt dissolution differently for square and triangular waveforms as in the later case, $\mathrm{Cl}_{2}$ concentrations decrease significantly through its reduction and diffusion before the reduction of Pt-Oxides. However, to avoid significant chlorine evolution/carbon corrosion and to obtain a high dissolution rate, the upper potential limit in the present study has been restricted to $1.6 \mathrm{~V}$..

Apart from optimization of the working potential window, the upper/lower potential limit studies shed light on the overall dissolution mechanism. The dissolution takes place by chloride complexing through equations (2) and (3) for potentials $>0.75 \mathrm{~V}$, along with parallel formation of Pt-Oxide layer through equations (4), (5) and (6). ${ }^{[18,46-47]}$ During the cathodic sweep, Pt-dissolution takes place through dissolution/chloride complexing of the Pt-Oxide layer, leading to a fresh Pt surface for potentials ranging between 1.0 and $0.4 \mathrm{~V}$. The potential value sufficient to dissolve the Pt-oxide layer completely may be varied by varying the reaction kinetics by changing the parameters such as scan rate, Pt-nanoparticle/support interface, etc. The local potential at the nanoparticle surface may differ significantly from the externally applied potential due to the insolating property of the proton conductive polymer and the ionomer (thin film) encapsulating catalyst interface structure, ${ }^{[48-50]}$ where 
there is an increased electron transport resistance at the catalyst/support/ionomer interface. ${ }^{[49,51]}$ Therefore, the values reported in the study is specific for the PEMFC electrodes; nevertheless, the relative value and changing trend is representative and can be used for general understanding. Further, as the cathodic peaks corresponding to $\mathrm{Cl}^{-}$desorption/Pt-Oxide reduction during negative-going scan in $0.1 \mathrm{M} \mathrm{HCl}$ (Fig. 3a) shift towards negative potentials with increasing the upper potential limit, the potential range for dissolution may be optimized further through choosing a smaller potential step (e.g. 100 or $50 \mathrm{mV}$ ) for the lower/upper potential limit study, instead of a potential step of $200 \mathrm{mV}$ used in the present study.

$$
\begin{aligned}
& {\left[\mathrm{PtCl}_{4}\right]^{2-}+2 e^{-} \rightarrow \mathrm{Pt}+4 \mathrm{Cl}^{-}\left(E^{o}=0.75 \mathrm{~V}\right)} \\
& {\left[\mathrm{PtCl}_{6}\right]^{2-}+2 e^{-} \rightarrow\left[\mathrm{PtCl}_{4}\right]^{2-}+2 \mathrm{Cl}^{-}\left(E^{o}=0.68 \mathrm{~V}\right)} \\
& \mathrm{PtO}+2 \mathrm{H}^{+}+2 e^{-} \rightarrow \mathrm{Pt}+\mathrm{H}_{2} \mathrm{O}\left(E^{o}=0.88 \mathrm{~V}\right) \\
& \mathrm{PtO}_{2}+2 \mathrm{H}^{+}+2 e^{-} \rightarrow \mathrm{PtO}+\mathrm{H}_{2} \mathrm{O}\left(E^{o}=1.01 \mathrm{~V}\right) \\
& \mathrm{PtO}_{2}+4 \mathrm{H}^{+}+4 e^{-} \rightarrow \mathrm{Pt}+2 \mathrm{H}_{2} \mathrm{O}\left(E^{o}=1.00 \mathrm{~V}\right)
\end{aligned}
$$

Further, redeposition of the dissolved Pt on the source Pt-nanoparticles or on the WE surface may take place through equations (2) and (3) for potentials below the Nernst potential.

Nernst equations corresponding to eq. (2) and (3) can be written as equations (7) and (8), respectively,

$$
\begin{aligned}
& E=E^{0}-\frac{R T}{n F} \ln \left(\frac{a_{C l^{-}}^{4}}{a_{\left[P t C l_{4}\right]^{2-}}}\right) \\
& E=E^{0}-\frac{R T}{n F} \ln \left(\frac{a_{\left[P t C l_{4}\right]^{2-}} \times a_{C l^{-}}^{2}}{a_{\left[P t C l_{6}\right]^{2-}}}\right)
\end{aligned}
$$

where $E$ and $E^{0}$ are the Nernst and the standard redox potentials, $\mathrm{R}$ is the gas constant, $\mathrm{T}$ is the Temperature $(\mathrm{K}), \mathrm{F}$ is the Faraday constant and $n$ is the number of electrons in half-reaction and $a_{x}$ is the activity of the species $x$.

For estimation of the Nernst potentials corresponding to dissolution or redeposition of $\mathrm{Pt}$, the equilibrium $\left[\mathrm{PtCl}_{4}\right]^{2-}$ concentration is assumed to be $5 \%$ of the $\left[\mathrm{PtCl}_{6}\right]^{2-}$ concentration, 
considering the fact that no significant fraction of $\left[\mathrm{PtCl}_{4}\right]^{2-}$ is observed in the electrolyte. For typical Pt concentrations of Table $2(\leq 0.5 \mathrm{mM})$ and $\mathrm{Cl}^{-}$concentration of $0.1 \mathrm{M}$, in the present study, the Nernst potentials corresponding to eq. (1) and (2) are estimated to be 0.73 and $0.78 \mathrm{~V}$, respectively. However, the effect of redeposition on the \%dissolution is observable for the lower potential limits $<0.4 \mathrm{~V}$ (Fig. 3b). This may be attributed to combined effects of the increasing \%dissolution through complete dissolution of Pt-Oxide and the reaction overpotential for Pt redeposition shifting the redeposition potential towards lower values. 

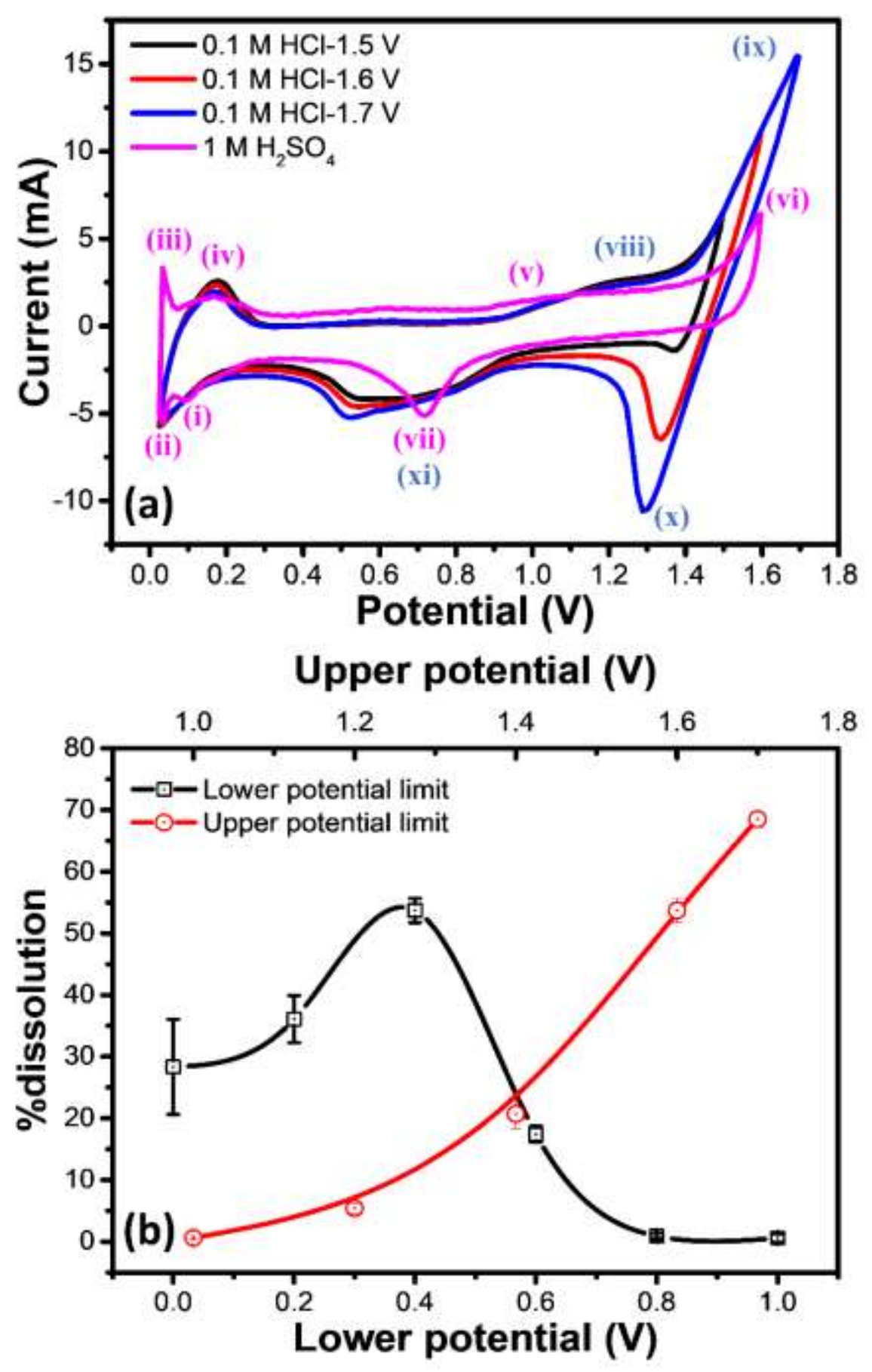

Fig. 3: Cyclic voltammograms in $0.1 \mathrm{M} \mathrm{HCl}$ or $1 \mathrm{M} \mathrm{H}_{2} \mathrm{SO}_{4}$ at a scan rate of $10 \mathrm{mV} / \mathrm{s}$. Peaks corresponding to various Faradaic reaction are labeled as- (i) $\mathrm{H}^{+}$adsorption, (ii) hydrogen evolution, (iii) HOR, (iv) $\mathrm{H}^{+}$desorption, (v) Pt oxidation, (vi) oxygen evolution/carbon corrosion, (vii) Pt-Oxide reduction, (viii) $\mathrm{Cl}^{-}$adsorption, (ix) chlorine evolution, (x) chlorine reduction and (ix) 
$\mathrm{Cl}^{-}$desorption. (b) Variations of \%dissolution of Pt from WE with the lower potential limit and the higher potential limits during potential cycling.

\subsection{Effects of $\mathrm{H}^{+}$and $\mathrm{Cl}^{-}$concentrations}

Electrolytes without $\mathrm{Cl}^{-}$as complexing agents: In absence of $\mathrm{Cl}^{-}$as complexing agent, no significant dissolution of Pt takes place. As an example, potential cycling of the PEMFC electrodes (10 mm diameter) between 0.4 and $1.6 \mathrm{~V}$ in $0.1 \mathrm{M}, 1 \mathrm{M}$ and $4 \mathrm{M}$ nitric acid for 100 cycles at a scan rate of $100 \mathrm{mV} / \mathrm{s}$ exhibits \%dissolutions of $\sim 0.3 \%, 1.8 \%$ and $3.6 \%$, respectively. Moreover, increasing the $N$ does not seem to increase the \%dissolution proportionally. For example, 2500 potential cycles $(0.4$ and $1.6 \mathrm{~V}$; scan rate: $100 \mathrm{mV} / \mathrm{s}$ ) in $0.1 \mathrm{M} \mathrm{HNO}_{3}$ exhibit a \%dissolution of $1.2 \%$. Further, increasing the $\mathrm{NO}_{3}{ }^{-}$concentration by adding $\mathrm{NH}_{4} \mathrm{NO}_{3}$ does not improve the dissolution significantly (supporting information: S2). Similar observations of low \%dissolution of $\mathrm{Pt}$ in other $\mathrm{Cl}^{-}$free electrolytes such as $1 \mathrm{M} \mathrm{H}_{2} \mathrm{SO}_{4}$ and $0.1 \mathrm{M} \mathrm{HClO}_{4}$ have also been made in our previous studies. ${ }^{[31,52-53]}$ Hence, in absence of complexing agents, very little amount of $\mathrm{Pt}$ was removed from the WE due to the unstable nature of the Pt-Oxides formed at potentials higher than $\sim 1 \mathrm{~V}$ at the low $\mathrm{pH}$ values of the studied electrolytes $^{[54]}$ and high tendency for redeposition. However, the average Pt-nanoparticle size increases during the electrochemical treatment due to Ostwald ripening. ${ }^{[31,53]}$ For example, the crystallite size of the electrode subjected to potential cycling $(0.4-1.6 \mathrm{~V} ; 100 \mathrm{mV} / \mathrm{s})$ for 200 cycles in $1 \mathrm{M} \mathrm{HNO}_{3}$ is observed to be $3.1 \mathrm{~nm}$ as compared to $2.0 \mathrm{~nm}$ of the pristine electrode (supporting information: S3).

Electrolytes with $\mathrm{Cl}^{-}$as complexing agents: Dissolution of $\mathrm{Pt}$ in presence of $\mathrm{Cl}^{-}$may take place at comparatively lower potentials through equations (2) and (3). The potential vs. pH diagram in presence of $\mathrm{Cl}^{-}$suggests the dissolution potential to be independent for a broad range of $\mathrm{pH}$ between 0 and $\sim 6{ }^{[41]}$ Fig. 4a shows a comparison of the \%dissolution values in $0.1 \mathrm{M}$ and $1 \mathrm{M} \mathrm{HCl}$ electrolytes, 
exhibiting a clear enhancement of dissolution rate with the $\mathrm{HCl}$ concentration. The most efficient Ptdissolution in $1 \mathrm{M} \mathrm{HCl}$, reaching to $\sim 95 \%$ dissolution in 50 cycles may be compared with that in 0.1 $\mathrm{M} \mathrm{HCl}$, where 250 potential cycles produced $\sim 90 \%$ dissolution. However, the first derivative (d(\%dissolution)/d $N$; \%dissolution/cycle) decreases sharply with increasing $N$ due to the decreasing fraction of undissolved small Pt nanoparticles, higher Pt concentration in the electrolyte and therefore higher probability of redeposition. The estimated average rate of Pt-dissolution/cycle for the first two cycles in $1 \mathrm{M} \mathrm{HCl}$ is $\sim 30 \mu \mathrm{g} /$ cycle.
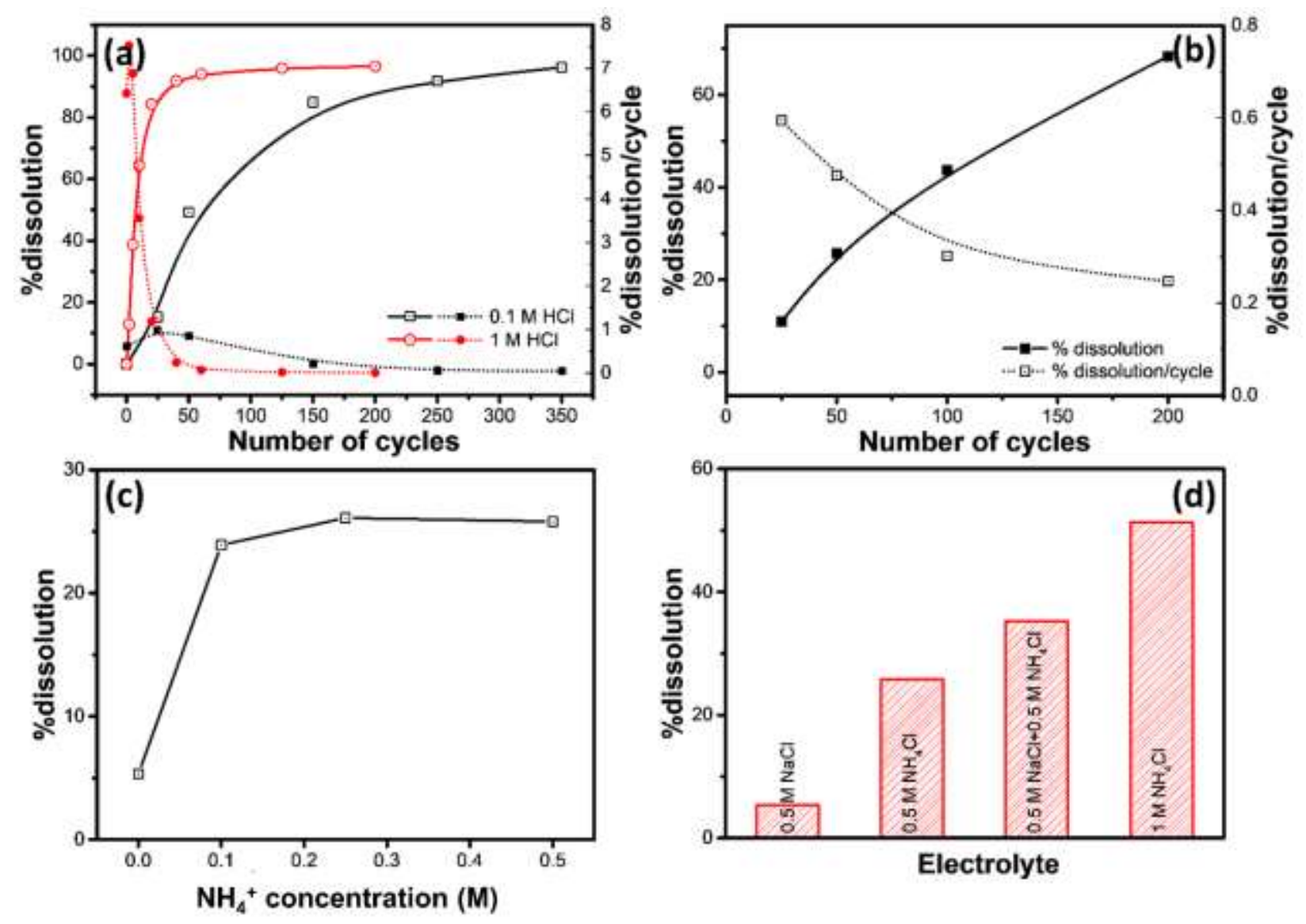

Fig. 4: Variations of \%dissolution and \%dissolution/cycle vs. number of cycles for electrochemical dissolution in (a) $0.1 \mathrm{M}, 1 \mathrm{M} \mathrm{HCl}$ and (b) $0.5 \mathrm{M} \mathrm{NH}_{4} \mathrm{Cl}$ electrolytes. Variation of \%dissolution during electrochemical dissolution in different electrolytes through potential cycling (potential 
range: $0.4-1.6 \mathrm{~V}$; scan rate: $100 \mathrm{mV} / \mathrm{s})$ for 50 cycles with (c) varying the $\mathrm{NH} 4^{+}$concentration $\left(\mathrm{Cl}^{-}\right.$ concentration: $0.5 \mathrm{M}$ ) and (d) varying both the $\mathrm{NH}^{+}$and the $\mathrm{Cl}^{-}$concentrations.

Pt-dissolution in acid-free baths: Apart from dilute acidic baths i.e. $0.1 \mathrm{M} \mathrm{HCl}, \mathrm{Pt}$ dissolution in acid-free baths such as aqueous solutions of $\mathrm{NH}_{4} \mathrm{Cl}$ or $\mathrm{NaCl}$ has been demonstrated. Electrochemical dissolution studies in the $\mathrm{NH}_{4} \mathrm{Cl}$ or $\mathrm{NaCl}$ baths have been performed through potential cycling between 0.4 and $1.6 \mathrm{~V}$ at a scan rate of $100 \mathrm{mV} / \mathrm{s}$ for a specified value of $N$. Fig.4b shows the variations of \%dissolution and $\mathrm{d}\left(\%\right.$ dissolution)/d $N$ with $N$ in $0.5 \mathrm{M} \mathrm{NH}_{4} \mathrm{Cl}$. With $\sim 70 \%$ dissolution in the first 200 cycles, the acid-free electrolyte exhibits promising performance. Furthermore, Fig. 4c exhibits the impact of the $\mathrm{NH}_{4}{ }^{+}$concentration $\left(\mathrm{Cl}^{-}\right.$concentration: $0.5 \mathrm{M}$; adjusted by $\left.\mathrm{NaCl}\right)$ on the \%dissolution of Pt during potential cycling for 50 cycles between 0.4 and $1.6 \mathrm{~V}$ at a scan rate of $100 \mathrm{mV} / \mathrm{s}$. As shown in Fig. 4d, potential cycling $(0.4-1.6 \mathrm{~V} ; 100 \mathrm{mV} / \mathrm{s} ; 50$ cycles) in a $0.5 \mathrm{M} \mathrm{NH} 4 \mathrm{Cl}$ bath exhibits 5 times higher \%dissolution of $\mathrm{Pt}$ as compared to that in a $0.5 \mathrm{M} \mathrm{NaCl}$ bath. This is due to the fact that the dissolution potentials remain constant for $\mathrm{pH}$ below $\sim 6$ in $\mathrm{Cl}^{-}$containing electrolytes, and the dissolution takes place through equations (2) and (3). However, for $\mathrm{pH}>6$, the dissolution takes place through formation of $\mathrm{Pt}(\mathrm{OH})_{2}$ rather than through the $\left[\mathrm{PtCl}_{\mathrm{x}}\right]^{2-}$ complexes. ${ }^{[41]}$ UV-vis spectrum of the dissolved Pt species in $0.5 \mathrm{M} \mathrm{NaCl}(\mathrm{pH} 7)$ through 50 cycles between 0.4 and $1.6 \mathrm{~V}$ at a scan rate of $100 \mathrm{mV} / \mathrm{s}$ is shown in Fig. S3 (supporting information S4). The spectrum does not show peaks corresponding to either of the $\left[\mathrm{PtCl}_{4}\right]^{2-}$ or $\left[\mathrm{PtCl}_{6}\right]^{2-}$ complexes and therefore the \%dissolution remains comparable to that observed for the $\mathrm{Cl}^{-}$free electrolytes.

Further, for the $\mathrm{Cl}^{-}$concentrations of $1 \mathrm{M}$ and in presence of $\mathrm{NH}_{4} \mathrm{Cl}$ higher $\mathrm{NH}_{4}{ }^{+}$concentration leads to higher \%dissolution. This may be attributed to (i) the relatively higher acidic nature of the $0.5 \mathrm{M}$ $\mathrm{NH}_{4} \mathrm{Cl}$ electrolyte ( $\mathrm{pH}: \sim 4.5$ ) as compared to the neutral $\mathrm{NaCl}$ electrolyte leading to dissolution 
through formation of the $\left[\mathrm{PtCl}_{\mathrm{x}}\right]^{2-}$ complexes and (ii) the enhanced reaction kinetics due to lower solubility of the dissolution product $\left(\mathrm{NH}_{4}\right)_{2} \mathrm{PtCl}_{6}$.

Effect of electrolyte convection flow: The potential limit study suggests redeposition of the dissolved Pt specices, especially for potentials below $0.5 \mathrm{~V}$ during the electrochemical potential cycling. Using identical location scanning electron microscope (IL-SEM) imaging of the electrochemically degraded electrodes, Hodnik et al. (2013) have observed a three-dimensional Ostwald ripening by the Pt dissolution from inner layers and redeposition of the dissolved Pt species on the top layers of a thin-film catalyst. ${ }^{[55]}$ Hence, the rate of redeposition of the dissolved Pt species is expected to increase with increasing their local concentration in proximity of the electrode. Comparison of \%dissolution values for Pt dissolution through potential cycling between 0.4 and 1.6 $\mathrm{V}$ at a scan rate of $10 \mathrm{mV} / \mathrm{s}$ in $0.1 \mathrm{M} \mathrm{HCl}$ for 25 cycles with or without stirring the electrolyte suggests large enhancement of the dissoluton rate. Under identical conditions, the \%dissolution increases form $\sim 16 \%$ for the stagnent electrolyte to $\sim 80 \%$ for the electrolyte stirred at $750 \mathrm{rpm}$. This large enhancement of \%dissolution may be attributed to the fact that in absence of convection flow, concentrations of the dissolved Pt species in proximity of the Pt nanoparticles remain high in the stagnent electrolyte as compared to those in the stirred electrolyte, leading to high rate of redeposition of the dissolved Pt species and hence lower \% dissolution.

\subsection{Electrode interface influence on Pt catalyst dissolution}

Most PEMFC electrodes consist of a mixture of the carbon supported Pt-nanoparticles and the proton conducting ionomer (e.g. Nafion ${ }^{\circledR}$ ) coated on the GDL. The catalyst/ionomer interface has been reported to affect the electrochemical catalytic performance of the electrode significantly. ${ }^{[48,56-58]}$ The catalyst/ionomer interface may similarly affect the Pt/electrolyte interaction, ${ }^{[50,59]}$ and hence the Ptdissolution during the electrochemical treatment. To study the impact of catalyst/ionomer interface on the Pt-dissolution, PEMFC electrodes having different catalyst ink compositions with Nafion ${ }^{\circledR}$ 
contents of $0,15,30$ and 45 wt.\% were studied. Potentiodynamic dissolution through potential cycling (potential range: $0.4-1.6 \mathrm{~V}$; scan rate: $100 \mathrm{mV} / \mathrm{s}$ ) for 25 cycles in $0.1 \mathrm{M} \mathrm{HCl}$ shows different \%dissolution values with different ionomer contents (Fig. 5a). This series of electrodes are more prone to platinum dissolution than the electrodes used for the other experiments of this study, which might be due to their more open electrode structure created by the spray coating method rather than the tape casting used for the later ones. High \%dissolution for the electrode with $0 \%$ Nafion ${ }^{\circledR}$ content as compared to those with higher Nafion ${ }^{\circledR}$ contents suggests the significant hindrance of the Nafion ${ }^{\circledR}$ on the dissolution process. This may be attributed to the low diffusion coefficients or repulsion from negative charges of the $\left[\mathrm{PtCl}_{4}\right]^{2-}$ and $\left[\mathrm{PtCl}_{6}\right]^{2-}$ complexes in the cation exchange resin Nafion ${ }^{\circledR}$ as compared to those in the aqueous electrolyte. This may increase local concentrations of the dissolved Pt species and hence lead to higher redeposition. Additionally, formation of Pt nanoparticles inside the ionomer through reduction of the Pt species migrated inside the ionomer membrane, a mechanism similar to that observed during electrode degradation in PEMFCs by reduction of the $\mathrm{Pt}$ species through the crossed-over hydrogen, ${ }^{[60-61]}$ might play a role. At the electronically connected carbon/ionomer interface, reduction of the entrapped $\mathrm{Pt}$ species during negative-going potential scan may take place.

Further, the slightly increasing Pt dissolution trend with increasing ionomer content $(15,30$ and 45 wt.\%) might be attributed to the more accessible Pt surface due to ionomer agglomeration at high concentration. ${ }^{[56]}$ XRD patterns of the pristine electrodes (Fig. 5b) with different Nafion ${ }^{\circledR}$ content show similar peak widths for the Pt (111) peak, eliminating the possibility of initially different particle sizes. The XRD patterns of the post-dissolution electrodes show a marginal increase of the particle $\operatorname{sizes}(\sim 5 \%)$. 

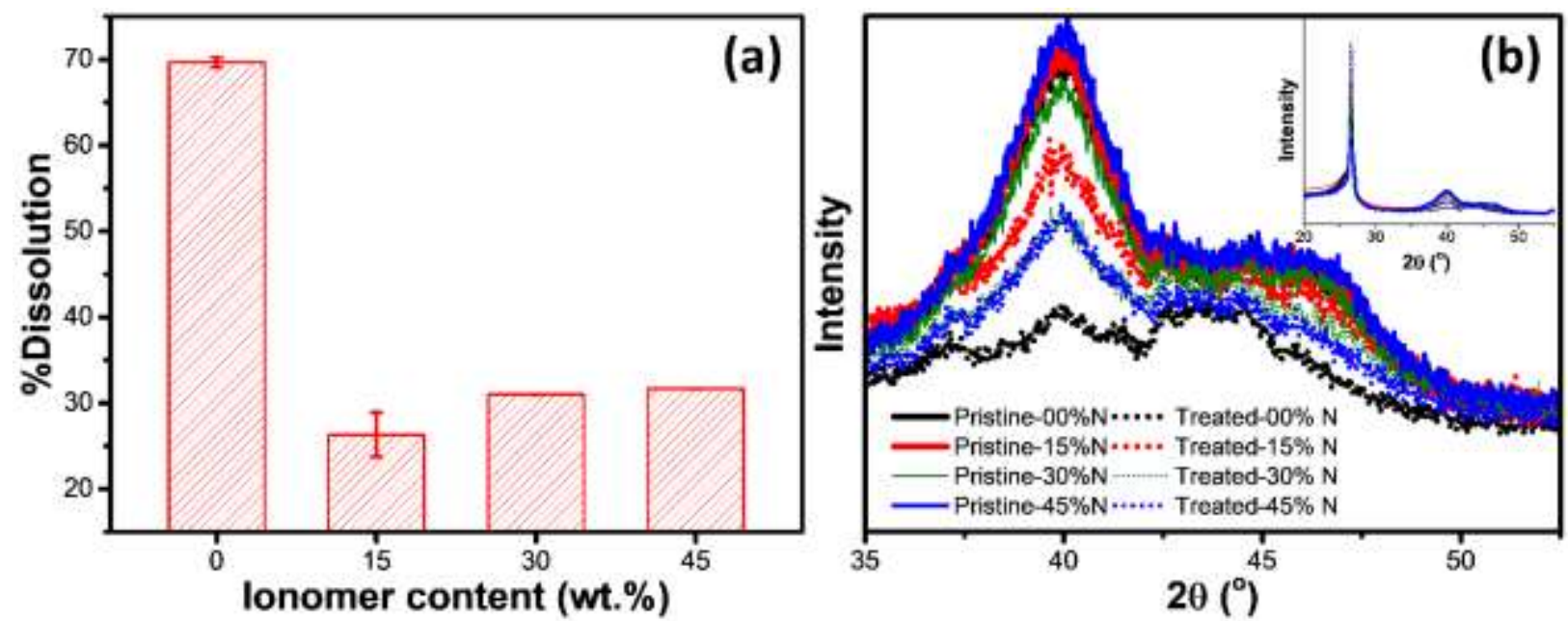

Fig. 5: (a) Variation of \%dissolution for electrochemical dissolution in $0.1 \mathrm{M} \mathrm{HCl}$ through potential cycling (potential range: $0.4-1.6 \mathrm{~V}$; scan rate: $100 \mathrm{mV} / \mathrm{s}$ ) for 25 cycles. (b) XRD patterns of pristine and post-dissolution electrodes with different Nafion ${ }^{\circledR}$ contents, showing the Pt (111) and Pt (200) peaks at $2 \theta$ values $\sim 39.9^{\circ}$ and $46.1^{\circ}$, respectively. The inset of (b) shows the XRD patterns for a broader scan range.

\subsection{Dissolution product and electrode structure evolution during dissolution}

Recovery of spent catalysts through electrochemical dissolution of Pt may be achieved by using the electrolytes containing the species that form stable Pt complexes. Electrochemical dissolution of Pt in presence of $\mathrm{Cl}^{-}$leads to formation of $\mathrm{Pt}$ complexes. As can be seen from the UV-Vis spectra of the post-dissolution electrolytes. Fig. 6a shows the UV-vis spectra of the post-dissolution electrolytes for electrochemical Pt-dissolution studies by potential cycling in (i) $0.1 \mathrm{M} \mathrm{HCl}$ (25 cycles) and (ii) 0.5 $\mathrm{M} \mathrm{NH}_{4} \mathrm{Cl}$ (50 cycles) between 0.4 and $1.6 \mathrm{~V}$ at a scan rate of $100 \mathrm{mV} / \mathrm{s}$. Here, the samples were diluted appropriately using $0.1 \mathrm{M} \mathrm{HCl}$ or $0.1 \mathrm{M} \mathrm{NH}_{4} \mathrm{Cl}$ before the $\mathrm{UV}$-Vis measurements to obtain comparable absorbance values below 0.5. For comparison, UV-Vis spectra of commercial Pt precursors, namely $\mathrm{H}_{2} \mathrm{PtCl}_{6}$ and $\mathrm{K}_{2} \mathrm{PtCl}_{4}$ solutions in $0.1 \mathrm{M} \mathrm{HCl}$ exhibiting absorption peaks corresponding respectively to the $\left[\mathrm{PtCl}_{6}\right]^{2-}(265 \mathrm{~nm})$ and the $\left[\mathrm{PtCl}_{4}\right]^{2-}(225 \mathrm{~nm})$ complexes are 
also included. The UV-Vis spectra of the post-dissolution electrolytes show characteristics similar to that of the $\mathrm{H}_{2} \mathrm{PtCl}_{6}$. This confirms the chemical state of the dissolved $\mathrm{Pt}$ to be $\left[\mathrm{PtCl}_{6}\right]^{2-}$ complex for both of the electrolytes. To illustrate the reaction process, fig. $6 \mathrm{~b}$ shows the UV-vis spectra of the electrolyte $0.1 \mathrm{M} \mathrm{HCl}$ at different potentials during the first potential cycle with start, maximum, minimum and end potential values of $1.2 \mathrm{~V}, 1.6 \mathrm{~V}, 0.4 \mathrm{~V}$ and $1.6 \mathrm{~V}$, respectively. At the beginning of potential cycling from $1.2 \mathrm{~V}$ to positive-going segment $(1.2-1.6 \mathrm{~V}), \mathrm{Pt}$ dissolution takes place through formation of $\left[\mathrm{PtCl}_{4}\right]^{2-}$ species. During the negative-going scan from 1.6 to $0.8 \mathrm{~V}$, concentration of the $\left[\mathrm{PtCl}_{4}\right]^{2-}$ species increases, while it decreases for the scan from 0.8 to $0.4 \mathrm{~V}$. This decrease in the $\left[\mathrm{PtCl}_{4}\right]^{2-}$ species concentration may be attributed to their redeposition as $\mathrm{Pt}^{0}$. ${ }^{[24,31]}$ Further, the concentration of $\left[\mathrm{PtCl}_{6}\right]^{2-}$ species appears for the first time during the negative-going scan from 0.8 to $0.6 \mathrm{~V}$. The appearance of the absorption peak corresponding to $\left[\mathrm{PtCl}_{6}\right]^{2-}$ complex may be attributed to the Pt-dissolution through the Pt-Oxide removal below 1.0 V during negative-going scan, as has been observed in the corresponding cyclic voltammogram of Fig. 3a. Here, the fact that the sample collected at a certain potential for the UV-vis measurement may not represent the instantaneous concentration of the Pt species due to a time lag between their production and uniform distribution in the electrolyte. This may explain the first appearance of $\left[\mathrm{PtCl}_{6}\right]^{2-}$ species during the 0.8-0.6 segment, despite their formation during the 1.0-0.8 segment of the negative-going scan. Further, the nearly constant concentration of $\left[\mathrm{PtCl}_{6}\right]^{2-}$ species during the negative-going $(0.6-0.4 \mathrm{~V})$ and the positive-going (0.4-0.8 V) scans suggests no significant dissolution or redeposition of $\mathrm{Pt}$ taking place in this potential widow. The $\left[\mathrm{PtCl}_{6}\right]^{2-}$ concentration increases for the positive -going segment between 0.8 and $1.6 \mathrm{~V}$ due to anodic dissolution of Pt through formation of Pt-oxides. ${ }^{\text {[20] }}$ Here, the significant variation of the background below $220 \mathrm{~nm}$, possibly due to change in the $\mathrm{Cl}^{-}$ion concentration, however makes it difficult to comment on the $\left[\mathrm{PtCl}_{4}\right]^{2-}$ concentration. Nevertheless, unlike the first positive going segment between 1.2 and $1.6 \mathrm{~V}$, increase of the $\left[\mathrm{PtCl}_{6}\right]^{2-}$ concentration 
for the corresponding second positive going segment suggests different Pt dissolution mechanisms for the two cases, possibly due to the presence of intrinsic Pt-Oxide in the former case. Further investigations may be performed to understand the mechanisms. Also, real-time monitoring of the UV-vis spectra through flow-cell may be employed to observe the evolution of $\left[\mathrm{PtCl}_{4}\right]^{2-} /\left[\mathrm{PtCl}_{6}\right]^{2-}$ ratio during the potentiodynamic dissolution in presence of $\mathrm{Cl}^{-}$.
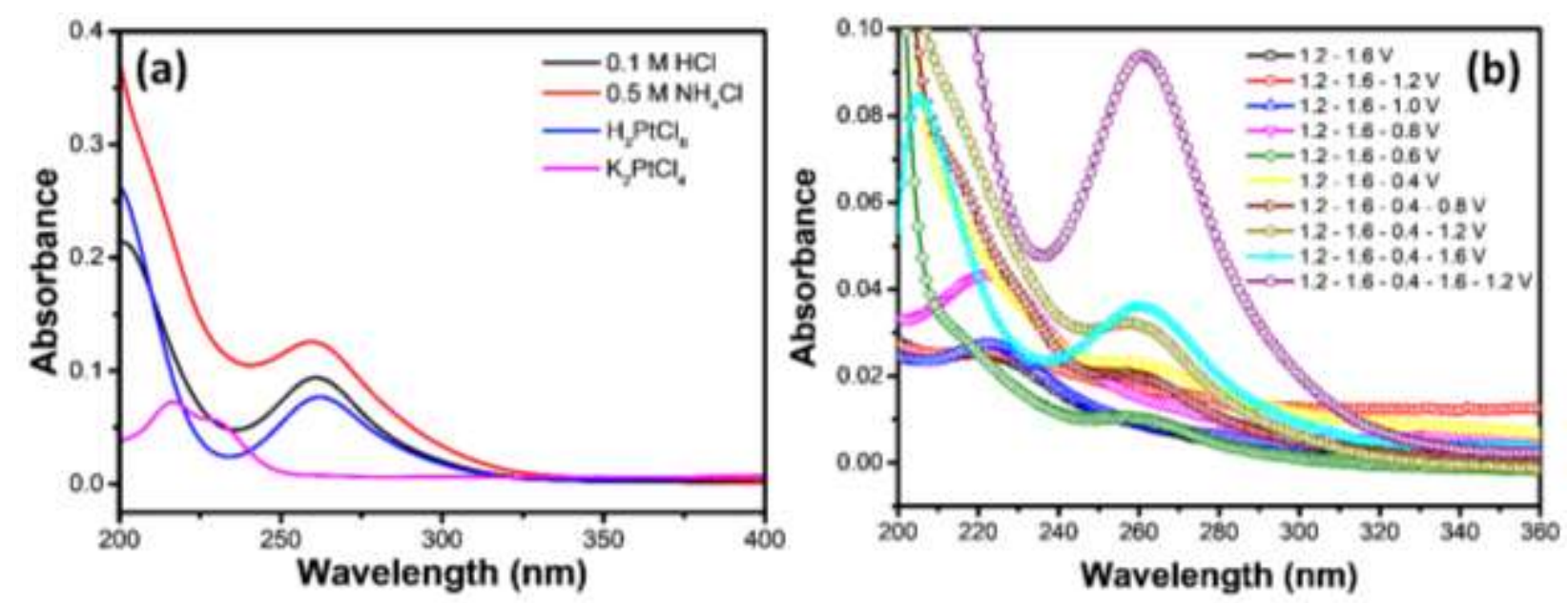

Fig. 6: (a) UV-Vis spectra of different post-dissolution electrolytes (potentiodynamic dissolution of Pt from the PEMFC electrode by potential cycling in $0.1 \mathrm{M} \mathrm{HCl}\left(25\right.$ cycles) and $0.5 \mathrm{M} \mathrm{NH}_{4} \mathrm{Cl}(50$ cycles) between 0.4 and $1.6 \mathrm{~V}$ at a scan rate of $100 \mathrm{mV} / \mathrm{s}$. For comparison, UV-Vis spectra of $\mathrm{H}_{2} \mathrm{PtCl}_{6}$ and $\mathrm{K}_{2} \mathrm{PtCl}_{4}$ solutions in $0.1 \mathrm{M} \mathrm{HCl}$ are also included. (b) $\mathrm{UV}$-vis spectra of the $0.1 \mathrm{M} \mathrm{HCl}$ electrolyte samples collected at different potentials during the first potential cycle. Legends show the additional potential sweep segment completed between the consecutive electrolyte sample collections.

Further, XRD patterns of the electrochemically treated post-dissolution electrodes treated by potential cycling between 0.4 and $1.6 \mathrm{~V}$ at a scan rate of $100 \mathrm{mV} / \mathrm{s}$ in $0.1 \mathrm{M} \mathrm{HCl}(25$ cycles $)$ and 1 in $1 \mathrm{M}$ $\mathrm{NH}_{4} \mathrm{Cl}$ (200 cycles) electrodes are shown in Fig. 7a and 6b, respectively. For comparison, XRD pattern of a pristine electrode is also included. The XRD pattern of pristine and $\mathrm{HCl}$ treated electrodes 
show diffraction peaks corresponding to both the graphitic carbon from GDL and the Ptnanoparticles. ${ }^{[31,52]}$ As shown in the inset of Fig. 7a, the decreased peak width of the diffraction for the post-dissolution sample suggests an increased average size of crystallites from $2.0 \mathrm{~nm}$ for pristine electrode to $2.4 \mathrm{~nm}$ for the post-dissolution electrode ( $25 \%$ dissolution). The crystallite growth may be attributed to the faster dissolution of the smaller particles and/or the growth of larger particles (Ostwald ripening). Further, the XRD patterns of the pristine and the post-dissolution electrode treated in $1 \mathrm{M} \mathrm{NH}_{4} \mathrm{Cl}$ are shown in Fig. 7b. The 'extra' diffraction peaks present in the pattern corresponding to the post-dissolution electrode suggest the presence of $\left(\mathrm{NH}_{4}\right)_{2} \mathrm{PtCl}_{6}$ deposits on the electrode during dissolution process, owing to its low solubility in the $1 \mathrm{M} \mathrm{NH}_{4} \mathrm{Cl}$ electrolyte. Hence, for the $\mathrm{NH}_{4} \mathrm{Cl}$ electrolyte, the dissolution product appears both in form of the $\left(\mathrm{NH}_{4}\right)_{2} \mathrm{PtCl}_{6}$ deposits ${ }^{[62]}$ on electrode and the $\left[\mathrm{PtCl}_{6}\right]^{2-}$ complex in the solution. On the other hand, the post-dissolution electrode treated in $0.1 \mathrm{HCl}$ shows no 'extra' peaks compared to the pristine electrode, suggesting the undissolved Pt to be in form of Pt-nanoparticles and hence the dissolution product to be in form of $\left[\mathrm{PtCl}_{6}\right]^{2-}$ complex in the solution.
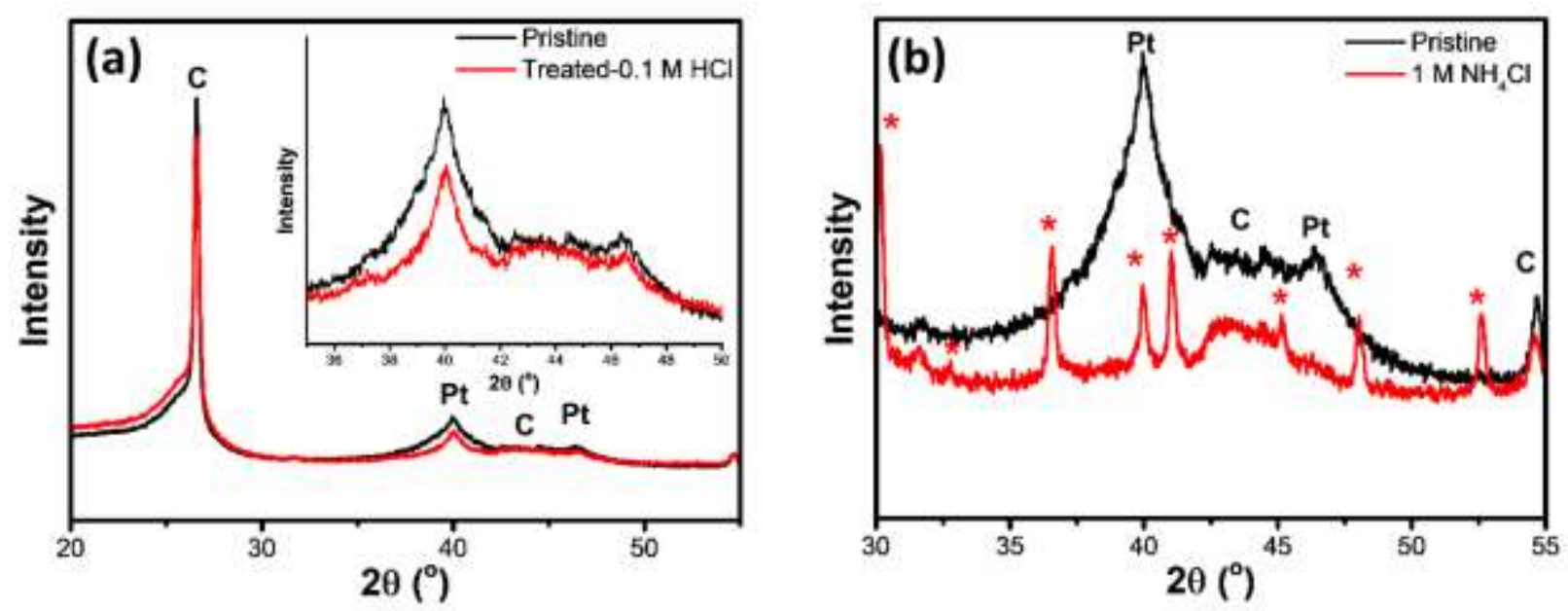

Fig. 7: XRD patterns of the electrochemically treated post-dissolution electrodes treated by potentialal cycling between 0.4 and $1.6 \mathrm{~V}$ at a scan rate of $100 \mathrm{mV} / \mathrm{s}$ in $0.1 \mathrm{M} \mathrm{HCl}(25$ cycles $)$ and 
in $1 \mathrm{M} \mathrm{NH}_{4} \mathrm{Cl}$ (200 cycles) electrodes. For comparison, XRD pattern of pristine electrode is also included. Diffraction peaks corresponding to $\left(\mathrm{NH}_{4}\right)_{2} \mathrm{PtCl}_{6}$ have been marked with (*).

Comparison between the TEM images of the pristine (fig. 8a) and the post-dissolution study electrodes (fig. 8b-8d) reveals significant reduction of $\mathrm{Pt}$ particle density during dissolution. However, different TEM images of the later reveal inhomogeneous distribution of the Ptnanoparticles in different areas of the electrode. The inhomogeneous dissolution could be due to the finite thickness of the catalyst layer where the top layer is exposed to the electrolyte most effectively while the inner layer of the catalyst layer is partially obscured. Significant growth of the particles, can be seen in Fig. 8b-8d, with larger particle size for smaller number density. As the XRD patterns suggest growth of crystallites with dissolution treatment, the growth of particle size observed from the TEM images may be attributed mainly to the Ostwald ripening (redeposition of the dissolved Pt species on the source Pt nanoparticles) along with other mechanisms such as particle agglomeration. Here, the redeposition probably takes place on the source Pt nanoparticles rather than formation of new particles on the carbon support. However, cross-sectional imaging of the post-dissolution electrodes may be performed to understand the redeposition process during the electrochemical dissolution. ${ }^{[55]}$ The dissolution efficiency may be enhanced significantly by using strategies to reduce the redeposition of dissolved Pt species. 

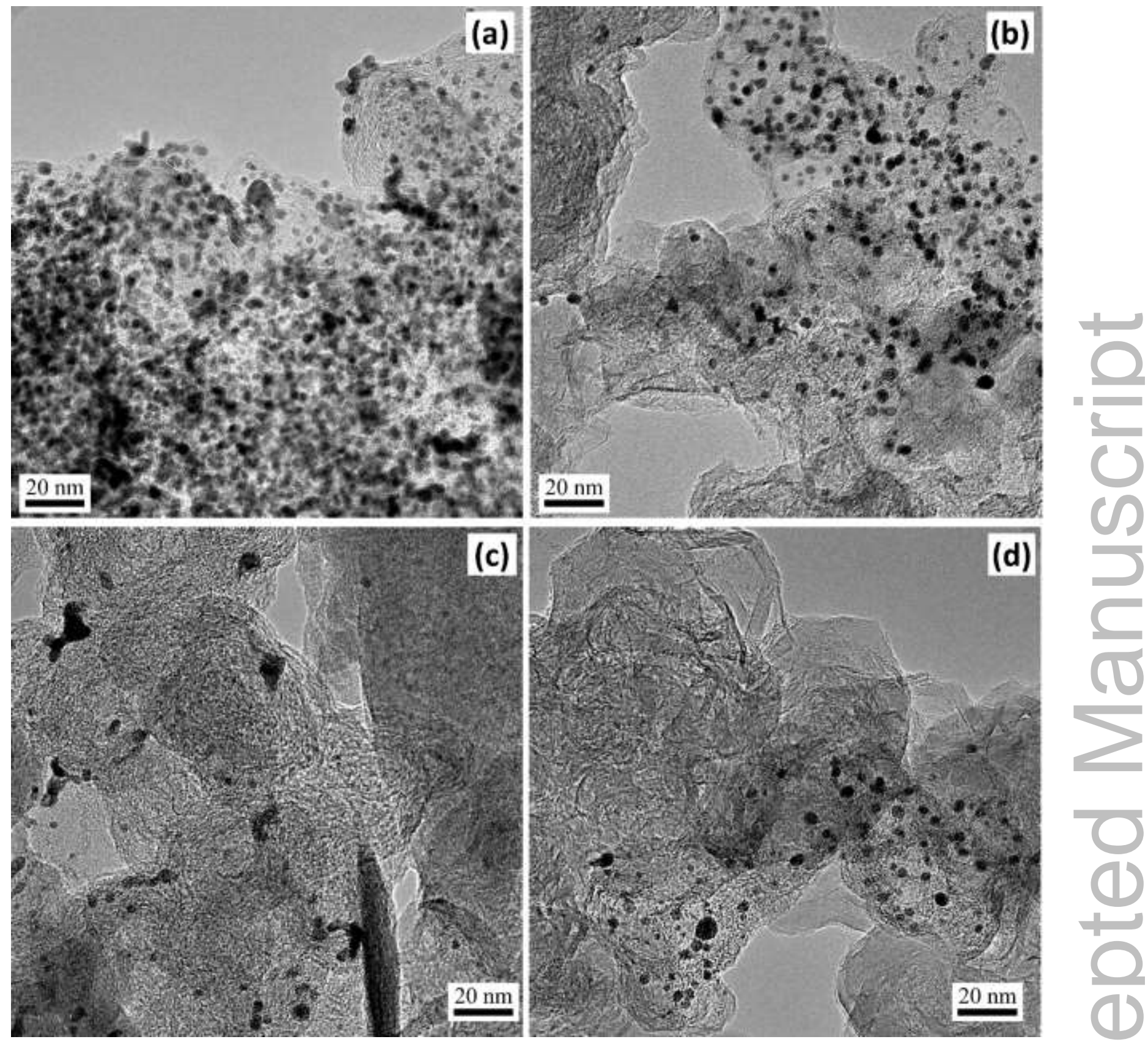

Fig. 8: TEM images of (a) the pristine and (b-d) the post-dissolution study (60\% dissolution)

electrodes.

\section{Upscaling for end-of-life MEA}

The presented electrochemical dissolution route is being explored towards its feasibility for the recovery of Pt from end-of-life MEAs. The initial challenge towards recycling Pt from the end-oflife MEAs is the delamination of the MEAs, necessary to make the catalyst layer accessible to the 
electrolyte. During delamination, the catalyst layers attach partially to the PEM, making it difficult to provide electronic connectivity for the potentiodynamic dissolution. Strategies addressing this issue may include the delamination with preferred attachment of the catalyst layer to the GDL, the separation of the catalyst from the PEM followed by the dissolution of Pt, etc. Moreover, \% Pt dissolution from different parts of a large electrode (e. g. $10 \times 10 \mathrm{~cm}^{2}$ ) varies significantly depending on the distance from the connection to the external circuit (low dissolution for areas far from the connection point). However, the issue can be solved by providing connections at multiple points. To summarize, the presented process to recover Pt electrocatalysts through potentiodynamic dissolution may be scaled up after solving such practical issues.

\section{Conclusions}

In conclusion, efficient recycling of precious metal catalysts supported on conductive substrates through potentiodynamic treatment under mild conditions has been studied. High activity of the nanoparticulate catalysts helps their faster dissolution in dilute acidic/acid-free chloride baths. The dissolution rate is influenced significantly by parameters such as the potential window, electrolyte composition, electrode interface, etc. A potential range between 0.4 and $1.6 \mathrm{~V}$ was found optimal for the typical PEMFC electrodes under study. Poor acidic and acid free $\mathrm{Cl}^{-}$containing electrolytes such as $0.1-1.0 \mathrm{M} \mathrm{HCl}$ and $0.5-1.0 \mathrm{M} \mathrm{NH}_{4} \mathrm{Cl}$ show efficient Pt recovery. For an initial Pt loading of $\sim 470$ $\mu \mathrm{g}$, an average rate of Pt-dissolution/cycle as high as $\sim 30 \mu \mathrm{g} / \mathrm{cycle}$ is achieved during potential cycling between 0.4 and $1.6 \mathrm{~V}$ in (scan rate: $100 \mathrm{mV} / \mathrm{s}$ ) in $1.0 \mathrm{M} \mathrm{HCl}$. In summary, the electrochemical dissolution route to recycle platinum catalyst from energy conversation systems presents an important recycling process and significant advance to sustain the green technologies.

\section{Acknowledgements}


The authors greatly appreciate the financial support from VILLUM FONDEN (blokstipendier), and SDU Proof of Concept grant.

\section{References}

[1] M. M. Whiston, I. L. Azevedo, S. Litster, K. S. Whitefoot, C. Samaras, J. F. Whitacre, Proc. Natl. Acad. Sci. 2019, 116, 4899-4904.

[2] Y.-J. Wang, W. Long, L. Wang, R. Yuan, A. Ignaszak, B. Fang, D. P. Wilkinson, Energy Environ. Sci. 2018, 11, 258-275.

[3] J. Stacy, Y. N. Regmi, B. Leonard, M. Fan, Renew. Sustain. Energy Rev. 2017, 69, 401-414.

[4] S. Martin, P. L. Garcia-Ybarra, J. L. Castillo, Electrochem. Commun. 2018, 93, 57-61.

[5] N. Jung, D. Y. Chung, J. Ryu, S. J. Yoo, Y.-E. Sung, Nano Today 2014, 9, 433-456.

[6] C. Zhu, H. Li, S. Fu, D. Du, Y. Lin, Chem. Soc. Rev. 2016, 45, 517-531.

[7] Y. Shao, J.-P. Dodelet, G. Wu, P. Zelenay, Adv. Mater., O, 1807615.

[8] S. Sui, X. Wang, X. Zhou, Y. Su, S. Riffat, C.-j. Liu, J. Mater. Chem. A 2017, 5, 1808-1825.

[9] G. M. Mudd, S. M. Jowitt, T. T. Werner, Sci. Total Environ. 2018, 622-623, 614-625.

[10] D. R. Lide, CRC handbook of chemistry and physics: a ready-reference book of chemical and physical data, 83 ed., CRC press, Boca Raton, FL, 2002.

[11] T. Bossi, J. Gediga, Johnson Matthey Tech. 2017, 61, 111-121.

[12] L. Duclos, J. Clean. Prod. 2017, v. 142, pp. 11-2628-2017 v.2142.

[13] Z. Peng, Z. Li, X. Lin, H. Tang, L. Ye, Y. Ma, M. Rao, Y. Zhang, G. Li, T. Jiang, JOM 2017, 69, 1553-1562.

[14] R. Wittstock, A. Pehlken, M. Wark, Recycling 2016, 1, 343-364.

[15] F. Xu, S. Mu, M. Pan, Int. J. Hydrog. Energy 2010, 35, 2976-2979. 
[16] L. Duclos, L. Svecova, V. Laforest, G. Mandil, P. X. Thivel, Hydrometallurgy 2016, 160, 79-89.

[17] Y. Sugawara, T. Okayasu, A. P. Yadav, A. Nishikata, T. Tsuru, J. Electrochem. Soc 2012, 159, F779-F786.

[18] S. Geiger, S. Cherevko, K. J. J. Mayrhofer, Electrochem. Acta 2015, 179, 24-31.

[19] C. Serhiy, K. G. P., G. Simon, Z. A. R., H. Nejc, K. Nadiia, M. K. J. J., ChemElectroChem 2015, 2, 1471-1478.

[20] T. A. A., K. Ioannis, A. Michael, C. Serhiy, M. J. C., K. S. O., M. K. J. J., Angew. Chem., Int. Ed. 2012, 51, 12613-12615.

[21] S. Cherevko, N. Kulyk, K. J. J. Mayrhofer, Nano Energy 2016, 29, 275-298.

[22] R. Sharma, S. Gyergyek, Q. Li, S. M. Andersen, J. Electroanal. Chem. 2019, 838, 82-88.

[23] P. Jovanovič, A. Pavlišič, V. S. Šelih, M. Šala, N. Hodnik, M. Bele, S. Hočevar, M. Gaberšček, ChemCatChem 2014, 6, 449-453.

[24] A. Pavlišič, P. Jovanovič, V. S. Šelih, M. Šala, N. Hodnik, M. Gaberšček, J. Electrochem. Soc 2018, 165, F3161-F3165.

[25] D. J. Myers, X. Wang, M. C. Smith, K. L. More, J. Electrochem. Soc 2018, 165, F3178F3190.

[26] N. Hodnik, B. Jozinović, M. Zorko, M. Gaberšček, Acta Chim. Slov. 2014, 61, 280.

[27] A. A. Topalov, S. Cherevko, A. R. Zeradjanin, J. C. Meier, I. Katsounaros, K. J. J. Mayrhofer, Chem. Sci. 2014, 5, 631-638.

[28] A. Pavlišič, P. Jovanovič, V. S. Šelih, M. Šala, N. Hodnik, S. Hočevar, M. Gaberšček, Chem. Commun. 2014, 50, 3732-3734.

[29] B. E. Myrzabekov, A. B. Bayeshov, A. B. Makhanbetov, B. Mishra, O. S. Baigenzhenov, Metall. Mater. Trans. B 2018, 49, 23-27. 
[30] S. Kanamura, M. Yagyu, Mater. Trans. 2016, 57, 1972-1976.

[31] R. Sharma, S. Gyergyek, S. M. Andersen, ChemSusChem 2018, 11, 3742-3750.

[32] N. Hodnik, C. Baldizzone, G. Polymeros, S. Geiger, J.-P. Grote, S. Cherevko, A. Mingers, A. Zeradjanin, K. J. J. Mayrhofer, Nat. Commun. 2016, 7, 13164.

[33] A. B. Ofstad, M. S. Thomassen, J. L. Gomez de la Fuente, F. Seland, S. Møller-Holst, S. Sunde, J. Electrochem. Soc 2010, 157, B621-B627.

[34] L. Xing, G. Jerkiewicz, D. Beauchemin, Anal. Chim. Acta 2013, 785, 16-21.

[35] S. Cherevko, A. R. Zeradjanin, G. P. Keeley, K. J. J. Mayrhofer, J. Electrochem. Soc 2014, 161, H822-H830.

[36] A. P. Yadav, T. Okayasu, Y. Sugawara, A. Nishikata, T. Tsuru, J. Electrochem. Soc 2012, 159, C190-C194.

[37] B. R. Shrestha, E. Tada, A. Nishikata, Electrochem. Acta 2014, 143, 161-167.

[38] Z. Wang, E. Tada, A. Nishikata, J. Electrochem. Soc 2014, 161, F845-F849.

[39] C. F. Nørgaard, S. N. Stamatin, E. M. Skou, Int. J. Hydrog. Energy 2014, 39, 17322-17326.

[40] J. Llopis, A. Sancho, J. Electrochem. Soc 1961, 108, 720-726.

[41] R. Latsuzbaia, E. Negro, G. J. M. Koper, ChemSusChem 2015, 8, 1926-1934.

[42] A. A. Topalov, A. R. Zeradjanin, S. Cherevko, K. J. Mayrhofer, Electrochem. Commun. 2014, 49-53.

[43] S. M. Andersen, R. Sharma, European application 2018, EP18 170312.

[44] M. Chourashiya, R. Sharma, S. M. Andersen, Anal. Chem. 2018, 90, 14181-14187.

[45] M. Łukaszewski, M. Soszko, A. Czerwiński, Int. J. Electrochem. Sci 2016, 11, 4442-4469.

[46] P. Vanysek, in CRC handbook of chemistry and physics (Ed.: D. R. Lide), CRC Press, Boca Raton, FL, 2005, pp. 8-23-28-33. 
[47] J. Schüring, H. D. Schulz, W. R. Fischer, J. Böttcher, W. H. Duijnisveld, Redox: fundamentals, processes and applications, Springer Science \& Business Media, 2013.

[48] S. M. Andersen, Appl. Catal. B 2016, 181, 146-155.

[49] A. Z. Weber, A. Kusoglu, J. Mater. Chem. A 2014, 2, 17207-17211.

[50] R. Sharma, S. M. Andersen, ACS Appl. Mater. Interfaces 2018, 10, 38125-38133.

[51] J. J. Conde, M. A. Folgado, P. Ferreira-Aparicio, A. M. Chaparro, A. Chowdhury, A. Kusoglu, D. Cullen, A. Z. Weber, J. Power Sources 2019, 427, 250-259.

[52] R. Sharma, S. M. Andersen, ACS Catal. 2018, 3424-3434.

[53] R. Sharma, S. M. Andersen, Appl. Catal. B 2018, 239, 636-643.

[54] M. Pourbaix, Atlas of electrochemical equilibria in aqueous solutions, National Association of Corrosion Engineers, Houston, Texas, 1984.

[55] N. Hodnik, M. Zorko, B. Jozinović, M. Bele, G. Dražič, S. Hočevar, M. Gaberšček, Electrochem. Commun. 2013, 30, 75-78.

[56] S. M. Andersen, L. Grahl-Madsen, Int. J. Hydrog. Energy 2016, 41, 1892-1901.

[57] A. S. Aricò, P. Cretì, P. L. Antonucci, J. Cho, H. Kim, V. Antonucci, Electrochem. Acta 1998, 43, 3719-3729.

[58] G. Doo, J. H. Lee, S. Yuk, S. Choi, D.-H. Lee, D. W. Lee, H. G. Kim, S. H. Kwon, S. G. Lee, H.-T. Kim, ACS Appl. Mater. Interfaces 2018, 10, 17835-17841.

[59] R. Sharma, L. Grahl-Madsen, S. M. Andersen, Mater. Chem. Phys. 2019, 226, 66-72.

[60] P. J. Ferreira, Y. Shao-Horn, Electrochem. Solid-State Lett. 2007, 10, B60-B63.

[61] N. Macauley, K. H. Wong, M. Watson, E. Kjeang, J. Power Sources 2015, 299, 139-148.

[62] Y. Verde-Gómez, G. Alonso-Nuñez, F. Cervantes, A. Keer, Mater. Lett. 2003, 57, 46674672. 